\title{
Utilisation of cholecystostomy and cystic duct as a route for percutaneous cutting balloon papillotomy and expulsion of common bile duct stones
}

\author{
Chwanrow Baban, ${ }^{1}$ Simon Rajendran, ${ }^{1}$ Deirdre O'Hanlon, ${ }^{1}$ Micheal Murphy² \\ 1Department of Surgery, South Infirmary Victoria University Hospital, Cork, Ireland; \\ 2Department of Radiology, South Infirmary Victoria University Hospital, Cork, Ireland
}

Correspondence to Dr Simon Rajendran, simonrajendran@gmail.com

\section{DESCRIPTION}

A 78-year-old male presented with jaundice, fever, rigors and right upper quadrant pain. Ultrasound demonstrated gallbladder empyema and common bile duct (CBD) stones with mild CBD dilatation. Medical morbidity and prior partial gastrectomy precluded endoscopic treatment. Under ultrasound guidance an 8fr Navarre pigtail drain (Bard Limited, UK) was inserted into the gall bladder and left insitu for 4 weeks. After 4 weeks, an 8fr Brite tip vascular sheath (Cordis-Europa, Netherlands) was introduced over a guidewire into the gallbladder via the cholecystostomy tract. A 5fr hydrophilic catheter (Cobra C2) and 0.035 guidewire (Terumo, Belgium) was used to traverse the cystic duct and CBD into the duodenum (figure $1 \mathrm{~A}, \mathrm{~B}$ ). The 0.035 wire was exchanged for a 0.018 VI8 Control Wire (Boston-Scientific, Natick, Massachusetts, USA) and an 8 $\mathrm{mm}$ peripheral cutting balloon was used to perform the papillotomy (figure 1C). Following papillotomy an $8 \mathrm{~mm}$
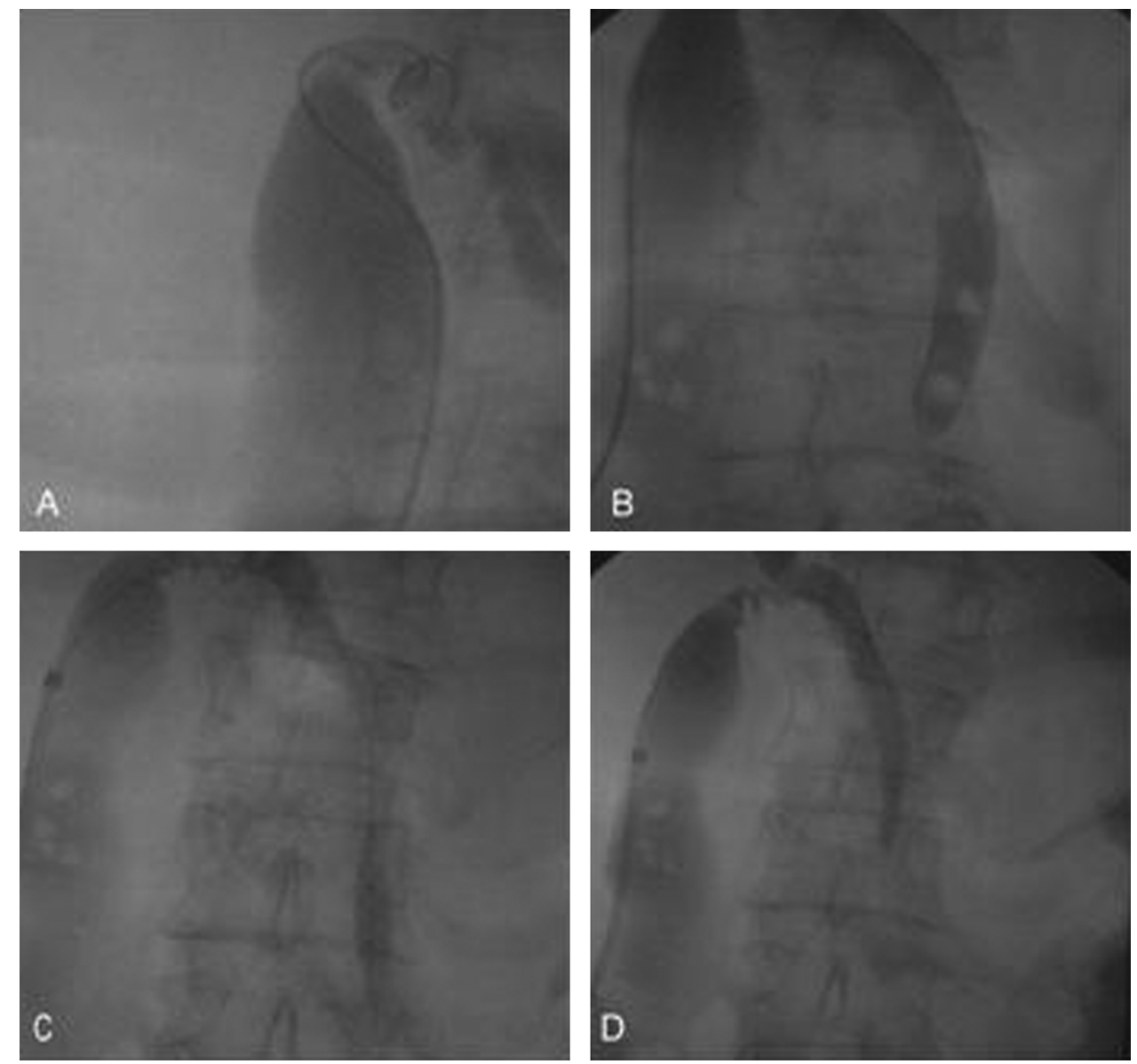

Figure 1 (A) Terumo Guide-wire and catheter traversing cystic duct. (B) Demonstrating gallbladder and common bile duct (CBD) stones with guidewire in CBD. (C) Demonstrating $8 \mathrm{~mm}$ cutting balloon inflated across the papilla. (D) Image postexpulsion of CBD stones. 


\section{BMJ Case Reports}

standard Wanda angioplasty balloon (Boston Scientific, Galway, Ireland) was used to push the 2 CBD stones into the duodenum (figure 1D). Subsequently, grasping forceps was used to retrieve the gallbladder stones via the cholecystostomy and drainage catheter was left insitu for 1 week. Postoperative recovery was uneventful. This is the first case describing cutting balloon papillotomy and expulsion of stones via cholecystostomy and cystic duct. The percutaneous transhepatic approach has previously been described. ${ }^{1-3}$ We report a safe alternative strategy to the transhepatic approach when endoscopic treatment is not feasible. This technique involves drainage of empyema to alleviate immediate danger and to provide access for subsequent papillotomy, CBD stone expulsion and gallbladder calculi retrieval.

\section{Competing interests None.}

Patient consent Obtained.

\section{REFERENCES}

1. Cotton PB, Lehman G, Vennes J, et al. Endoscopic sphincterotomy complications and their management: an attempt at consensus. Gastrointest Endosc 1991;37:383-93.

2. Vlavianos P, Chopra K, Mandalia S, et al. Endoscopic balloon dilatation versus endoscopic sphincterotomy for the removal of bile duct stones: a prospective randomised trial. Gut 2003;52:1165-9.

3. Oguzkurt L, Ozkan U, Gumus B. Percutaneous transhepatic cutting balloon papillotomy for removal of common bile duct stones. Cardiovasc Intervent Radiol 2009;32:1117-9.

This pdf has been created automatically from the final edited text and images.

Copyright 2012 BMJ Publishing Group. All rights reserved. For permission to reuse any of this content visit http://group.bmj.com/group/rights-licensing/permissions.

BMJ Case Report Fellows may re-use this article for personal use and teaching without any further permission.

Please cite this article as follows (you will need to access the article online to obtain the date of publication).

Baban C, Rajendran S, O'Hanlon D, Murphy M. Utilisation of cholecystostomy and cystic duct as a route for percutaneous cutting balloon papillotomy and expulsion of common bile duct stones. BMJ Case Reports 2012;10.1136/bcr.11.2011.5256, Published XXX

Become a Fellow of BMJ Case Reports today and you can:

- Submit as many cases as you like

- Enjoy fast sympathetic peer review and rapid publication of accepted articles

- Access all the published articles

- Re-use any of the published material for personal use and teaching without further permission

For information on Institutional Fellowships contact consortiasales@bmjgroup.com

Visit casereports.bmj.com for more articles like this and to become a Fellow

Keep up to date with all published cases by signing up for an alert (all we need is your email address) http://casereports.bmj.com/cgi/alerts/etoc 